JEMS (Jurnal Edukasi Matematika dan Sains), 8(2), 2020, 150-156

DOI: $10.25273 /$ jems.v8i2.6905

\title{
Profil Literasi Sains dan Berpikir Kreatif Siswa SMP Negeri 11 Pekalongan
}

\author{
Dianita Rokhmiati Ning, Feny Roshayanti, Joko Siswanto
}

(C) 2020 JEMS (Jurnal Edukasi Matematika dan Sains)

This is an open access article under the CC-BY-SA license (https://creativecommons.org/licenses/bysa/4.0/) ISSN 2337-9049 (print), ISSN 2502-4671 (online)

\begin{abstract}
Abstrak:
Penelitian ini bertujuan untuk mendiskrisikan 1. Profil literasi sains siswa, 2. Profil berfikir kreatif siswa kelas VII SMPN 11 Pekalongan pada materi klasifikasi makhluk hidup Tahun Pelajaran 2019/2020. Subjek penelitian adalah siswa kelas VII SMP N 11 Pekalongan sebanyak 34 siswa. Metode penelitian yang digunakan metode deskriptif kuantitatif. Pengambilan data menggunakan soal tes esai yang kemudian dijabarkan berdasarkan indikator literasi sains dan kreatif siswa. Berdasarkan hasil penelitian Kemampuan literasi sains siswa SMP N 11 Pekalongan dari skor maksimal 40 sebesar 11,6 ( $29 \%$ dan dilihat dari indikatornya siswa yang mampu memahami fenomena sebesar 38,15 (53\%), mengidentifikasi permasalahan ilmiah sebesar 2,1 (53\%), menjelaskan fenomena ilmiah sebesar 2,2 ( $57 \%)$, menggunakan bukti ilmiah sebesar 3,1 (79\%) dan menerapkan konsep sains secara personal,sosial dan global sebesar 2,5 ( 64\%).Sedang kemampuan berfikir kreatif siswa SMP N 11 Pekalongan adalah 16,6 (56\%) dari skor maksimal 32. Jika dilihat dari kemampuan siswa berdasarkan indikator kelancaran/ Fluency sebesar 1,6 (49\%), Keluwesan/ Flesibility sebesar 2,5 $(80 \%)$, keaslian/Originality sebesar 2,4 (75\%), Keterincian/Elaboration sebesar 1,8 (56\%).
\end{abstract}

Kata Kunci : Literasi sains; Berfikir kreatif.

\begin{abstract}
:
The purpose of this study is to describe 1. Profile of students' scientific literacy 2. Profile of creative thinking of Grade VII students of SMPN 11 Pekalongan on material classification of living things in 2019/2020 Academic Year. The subjects of the study were 34 students in grade VII of SMP N 11 Pekalongan. The research method used is quantitative descriptive method. Retrieval of data using essay test questions which are then described based on indicators of scientific and creative literacy of students. Based on the results of research the ability of scientific literacy of students of SMP N 11 Pekalongan from a maximum score of 40 is $11.6(29 \%)$ and seen from the indicators students are able to understand the phenomenon of 38.15 (53\%),identifying scientific problems of 2.1 (53\%), explain the scientific phenomena of $2.2(57 \%)$, use scientific evidence of 3.1 $(79 \%)$ and apply the concepts of science personally,socially and globally by $2.5(64 \%)$. While students' creative thinking abilities SMP N 11 Pekalongan is 16.6 (56\%) of the maximum score of 32. When viewed from the ability of students based on fluency indicators of $1.6(49 \%)$, Flexibility/ Flexibility of $2.5(80 \%)$, authenticity/ Originality of $2.4(75 \%)$, Elaboration/ Elaboration of $1.8(56 \%)$
\end{abstract}

Keyword: Science literacy; Creative thinking.

\section{Pendahuluan}

Pendidikan kita sekarang dihadapkan pada abad 21 yang menuntut manusia menyesuaikan perubahan pada berbagai aspek akibat kemajuan teknologi dan informasi. Pesatnya kemajuan teknologi pada abad 21 juga dibarengi dengan pesatnya perkembangan sains.

Dianita Rokhmiati Ning, Universitas PGRI Semarang

dian.nita566@gmail.com

Feny Roshayanti, Universitas PGRI Semarang

fennyroshayanti@upgris.ac.id

Joko Siswanto, Universitas PGRI Semarang

jokosispgri@gmail.com 
Dimana nantinya peserta didik dituntut harus mampu bersaing dan mengikuti arus globalisasi serta bisa berinovasi dan terampil dalam proses pembelajaran. Karena tuntutan tersebut maka peserta didik harus mempunyai kecakapan ketrampilan pembelajaran abad 21 yang terkenal dengan istilah $4 \mathrm{C}$ salah satunya adalah creativity thingking skill (ketrampilan berfikir kreatif ), dimana ketrampilan 4C juga tidak bisa terlepas dari ketrampilan litrerasi sains. Karna Literasi sains merupakan ketrampilan yang juga diperlukan pada abad 21 (Pertiwi et al, 2018)

Literasi sains adalah kemampuan menggunakan pengetahuan ilmiah, mengidentifikasi pertanyaan dan menggambarkan bukti - bukti yang berdasarkan kesimpulan untuk dapat memahami dan membantu pembuatan kesimpulan tentang alam serta perubahan terhadap alam tersebut akibat aktivitas manusia (PISA, 2010).

Berfikir kreatif adalah kemampuan siswa beradaptasi dengan masa depan dengan cara melatih kemampuan siswa melalui eksplorasi, inkuiri, penemuan dan pemecahan masalah dalam proses pembelajaran (Sunaryo, Y, Puspita L et ,2013,2018)

Salah satu kunci sukses mengahadapi tantangan abad 21 adalah "melek sains" (science Literacy), sebab individu yang melek sains merupakan salah satu sumber daya manusia yang dapat bersaing di abad 21, sehingga nantinya dapat menyiapkan peserta didik yang cakap dibidangnya dan mempunyai ketrampilan berfikir kreatif (Noviana , M, 2017).

Profil literasi sains dan berfikir kreatif peserta didik dapat diketahui menggunakan assessment atau penilaian untuk mengetahui sejauh mana kemampuan literasi sains dan berfikir kreatif peserta didik. Seperti halnya yang telah dilakukan oleh Organization for Economic Cooperation and Developmen (OECD) melalui program PISA untuk mengukur kemampuan pengetahuan serta sikap ilmiah siswa dalam kehidupan sehari-hari.

Pengukuran kemampuan literasi sains siswa di ukur dari 3 aspek yaitu aspek Konten, proses dan konteks, sedang berfikir kreatif siswa diukur dari 4 indikator yaitu kelancaran (Fluency), Keluwesan (flessibility), kemampuan berfikir rasional (Originality) dan ketrampilan memperinci (elaboration).

Berdasarkan penelitian literasi sains sebelumnya dengan judul "Profil literasi sains siswa SMP di kota Purwokerto ditinjau dari aspek konten, proses dan konteks sains (Mufida Noviana \& Teguh Julianto. 2017: 77-84) mendiskripsikan rata - rata prosentase kemampuan literasi sains siswa SMP Purwokerto masih rendah pada 3 aspek literasi sains yaitu aspek konten (53,80\%), Aspek Proses (44,038\%), Aspek Konteks (35,088\%) pada penelitian tersebut pengambilan data dengan jawaban - jawaban tes literasi sains siswa. Sehingga dari hasil jawaban- jawaban siswa tersebut menjadi acuan pemetaan kemampuan siswa dan kualitas pembelajaran sains (IPA).

Sedang untuk berfikir kreatif berdasarkan penelitian sebelumnya dengan judul " Profil kemampuan berfikir kreatif dan peningkatan hasil belajar kognitif siswa SMP melalui model pembelajaran kooperatif tipe STAD (Riski Mulyani dan Yudi Stiawan, 2014: 117-124) mendiskripsikan capaian aspek fluency (5\% tinggi, $80 \%$ sedang dan 15\% rendah), Flexibility (55\% sangat kreatif, $15 \%$ diatas rata-rata dan $30 \%$ rata-rata), Originality (25\% sangat kreatif, 35\% diatas rata-rata dan 40 rata-rata), elaboration (0\% istimewa, $0 \%$, sangat kreatif, $15 \%$ sangat baik diatas rata - rata, 30\% diatas rata-rata dan 15\% rata-rata) pengambilan data dengan tes pre tes dan post tes. Hasil penelitian tersebut masuk kategori baik.

Untuk meningkatkan kemampuan literasi sains dan berfikir kreatif siswa bisa mengunakan model pembelajaran level of inquiry merujuk N. P Anggi Putri Wijaya, dkk (2019). Tujuan penelitian ini adalah untuk mengetahui bagaimanakah profil literasi sains dan berfikir keatif siswa SMP Negeri 11 Pekalongan. 


\section{METODE}

Penelitian ini menggunakan metode deskriptif kuantitatif, yaitu penelitian yang bertujuan untuk menggambarkan capaian profil literasi sains dan berfikir kreatif siswa SMPN 11 Pekalongan. Penelitian ini dilakukan pada siswa kelas VII SMP N 11 Pekalongan sejumlah 34 siswa yang terdiri dari 19 laki - laki dan 15 perempuan yang ditetapkan secara random sampling.

Instrument yang digunakan adalah instrument tes literasi sains dan tes berfikir kreatif dalam bentuk soal esai. Literasi sains terdiri atas 3 aspek yang terbagi dalam 5 indikator dan setiap indikator diwakili oleh 2 soal sehingga total soal tes literasi sains ada 10 soal. Sedang berfikir kreatif terdiri atas 4 indikator dan setiap indikator diwakili oleh 2 soal sehingga total soal tes ketrampilan berfikir kreatif ada 8 soal. Setiap soal dinilai dengan skor 1-4 dengan kriteria masing - masing per indikator. Kemudian skor hasil jawaban siswa dihitung rata - ratanya, skor maksimum dan standar deviasi. Hasil ini kemudian digunakan untuk mengelompokkan kemampuan literasi sains dan ketampilan berfikir kreatif siswa kedalam predikat sangat kurang sampai cukup menurut aturan Purwanto (2009) sebagai berikut:

$$
\begin{array}{ll}
86-100 \% & =\text { Sangat baik } \\
76-85 \% & =\text { Baik } \\
60-75 \% & =\text { Cukup } \\
55-59 \% & =\text { Kurang } \\
\leq 54 \% & =\text { Sangat kurang }
\end{array}
$$

Kemudian dilakukan analisis rata-rata setiap indikator untuk mengatahui capaian setiap indikator terhadap kemampuan literasi siswa dan berfikir kreatif siswa

\section{Hasil dan Pembahasan}

\section{Data Literasi sains siswa}

Data Literasi sains siswa diperoleh melalui tes literasi sains dalam bentuk esai. Data hasil tes literasi sains siswa seperti table berikut:

Table 1. Rata-rata Skor Kemampuan Literasi Sains Siswa

\begin{tabular}{cc}
\hline Rata-rata Skor & $11,6(29 \%)$ \\
\hline Standar Deviasi & 2,1 \\
\hline Skor maksimum & 40 \\
\hline
\end{tabular}

Dari Tabel 1, kemampuan Literasi sains siswa dapat di kategorikan menjadi 4 seperti Tabel 2

Table 2. Tingkat Kemampuan Literasi Sains Siswa

\begin{tabular}{ccc}
\hline Kategori & Jumlah & Presentase \\
\hline Baik & 2 & $5,9 \%$ \\
\hline Cukup & 13 & $38,2 \%$ \\
\hline Kurang & 10 & $29,4 \%$ \\
\hline Sangat kurang & 9 & $26,5 \%$ \\
\hline
\end{tabular}

Dari hasil penelitian didapatkan bahwa rata-rata kemampuan litersasi sains siswa adalah 11,6 atau 29\%. dimana siswa yang sudah memiliki kemampuan literasi sains baik hanya 2 orang yang lainnya dalam kategori cukup, kurang dan sangat kurang. Kemampuan literasi sains siswa tersebut termasuk kedalam kategori kurang. Oleh karna itu kemampuan literasi sains siswa perlu 
ditingkatkan lagi dalam proses pembelajaran. Tingkat ketercapaian literasi sains siswa juga dapat dilihat dari setiap indikatornya.

Tabel 3. Rata-rata Skor Setiap Indikator Kemampuan Literasi Sains Siswa

\begin{tabular}{ccccc}
\hline $\begin{array}{c}\text { Aspek } \\
\text { Literasi sains }\end{array}$ & Indikator Literasi Sains & $\begin{array}{c}\text { Skor } \\
\text { Rata-rata }\end{array}$ & Presentase & Kategori \\
\hline Konten & Memahami fenomena & 1,5 & $38 \%$ & $\begin{array}{c}\text { Sangat } \\
\text { kurang }\end{array}$ \\
\hline Proses sains & $\begin{array}{c}\text { Mengidentifikasi } \\
\text { permasalahan ilmiah }\end{array}$ & 2,1 & $53 \%$ & $\begin{array}{c}\text { Sangat } \\
\text { kurang }\end{array}$ \\
\hline & $\begin{array}{c}\text { Menjelaskan fenomena secara } \\
\text { ilmiah }\end{array}$ & 2,2 & $57 \%$ & Kurang \\
\hline Konteks sains & $\begin{array}{c}\text { Menggunakan bukti ilmiah } \\
\text { Menerapkan konsep sains } \\
\text { secara personal, sosial dan } \\
\text { global }\end{array}$ & 2,1 & $79 \%$ & Baik \\
\hline
\end{tabular}

Dilihat dari hasil analisis data, diketahui bahwa hasil terbaik kemampuan literasi sains siswa terdapat pada aspek proses sains di indikator menggunakan bukti ilmiah. Pada indikator ini didapatkan rata-rata sebesar 3,1 atau 79\%. Dilihat dari kisi-kisi indikator soal ini siswa mampu menjawab pertanyaan dengan alasan yang tepat berdasarkan bukti-bukti ilmiah yang ada dilingkungan sekitar.

Sedangkan hasil literasi sains kategori sangat kurang adalah pada aspek konten dengan indikator memahami fenomena. Dengan capaian hasil sebesar 1,5 atau 38\%. Dilihat dari kisi-kisi indikator soal ini siswa belum mampu memberikan alasan yang tepat untuk menjawab pertanyaan, karena siswa tidak faham tentang fenomena - fenomena yang terjadi disekitar kita. Pada indikator ini perlu ditinjau kembali apakah penyebab rendahnya capaian indikator ini karena konteks soalnya ataukah pelaksaan proses pembelajaran disekolah

Selanjutnya indikator mengidentifikasi permasalahan ilmiah pada aspek proses sains memperoleh hasil 2,1 atau 53\%. Indikator ini juga termasuk dalam kategori sangat kurang. Hal ini dikarenakan masih banyak siswa yang belum mampu mengidentikasi permasalahan ilmiah disekitar mereka, atau seandanya mereka mampu mengidentifikasi permasalahan ilmiah dilingkungan sekitar tetapi alasan yang mereka gunakan untuk mengidentifikasi belum tepat. Indikator ini juga perlu ditinjau kembali apakah penyebab rendahnya capaian indikator adalah konteks soal yang sulit ataukah proses pembelajaran disekolah yang belum tepat.

Pada indikator menjelaskan fenomena secara ilmiah pada aspek proses sains memperoleh hasil sebesar 2,2 atau 57\%. Hal ini disebabkan siswa masih ada yang belum mampu memprediksi atau menafsirkan fenomena disekitar secara ilmiah serta perubahan yang terjadi akibat fenomena-fenomena tersebut tersebut.

Pada aspek yang ketiga yaitu aspek kontens sains dengan indikator menerapkan konsep sains secara personal, sosial dan global memperoleh hasil sebesar 2,5 atau 64\%. Indikator ini berada pada kategori cukup. Hal ini karna sudah banyak siswa yang mampu menerapkan konsep sains yang mereka dapat baik secara personal, sosial ataupun global.

Sangat kurangnya hasil kemampuan literasi sains siswa sesuai hasil penelitian bisa saja terjadi karena proses pembelajaran yang dilakukan hanya terfokus pada guru sehingga siswa hanya menerima informasi dari guru saja tanpa mencari literatur dari media lain, hal ini menyebabkan siswa hanya menghafalkan saja apa yang sampaikan guru dan tidak tau apa yang 
terjadi di lingkungan luar. Atau juga bisa terjadi karena siswa tidak terbiasa mengerjakan soal dalam bentuk soal cerita panjang. Oleh karna itu untuk meningkatkan kemampuan literasi sains siswa bisa dilakukan dengan mengubah proses pembelajaran berpusat pada siswa dengan model pembelajaran yang disarankan dalam kurikulum 13 salah satunya adalah dengan model pembelajaran levels of inquiry sehingga dapat membiasakan siswa mengerjakan soal tes dalam bentuk narasi atau cerita.

\section{Data berfikir kreatif siswa}

Data berfikir kreatif siswa didapat melalui tes berfikir kreatif siswa dalam bentuk soal esai. Adapun data hasil berfikir kreatif siswa adalah seperti tabel berikut:

Tabel 4. Rata-rata Skor Berfikir Kreatif Siswa

\begin{tabular}{c|c}
\hline Rata - rata Skor & $16,6(56 \%)$ \\
\hline Standar Deviasi & 1,9 \\
\hline Skor maksimum & 32 \\
\hline
\end{tabular}

Dari tabel 4, Berfikir kreatif siswa dapat dikategorikan menjadi 3 seperti tabel berikut:

Tabel 5. Tingkat kemampuan berfikir kreatif siswa

\begin{tabular}{ccc}
\hline Kategori & Jumlah & Prosentase \\
\hline Cukup & 8 & $23,5 \%$ \\
\hline Kurang & 8 & $23,5 \%$ \\
\hline Sangat kurang & 18 & $52,9 \%$ \\
\hline
\end{tabular}

Dari tabel hasil penelitian kemampuan berfikir kreatif siswa mendapatkan rata-rata sebesar 16,6 atau 56\%. Dari hasil tersebut siswa yang masuk katagori cukup hanya 8 orang, sedang yang lainnya berada di kategori kurang dan sangat kurang. Hasil capaian kemampuan berfikir kreatif siswa tersebut masuk dalam kategori kurang. Oleh karna itu kemampuan berfikir kreatif siswa perlu ditingkatkan lagi dalam proses pembelaran. Kemampuan berfikir kreatif siswa juga dapat dilihat pada tiap indikatornya.

Tabel 6. Rata-rata Skor Setiap indikator Kemampuan Berfikir Kreatif Siswa

\begin{tabular}{cccc}
\hline Indikator berfikir kreatif & Skor rata-rata & Prosentase & Kategori \\
\hline Kelancaran / fluency & 1,6 & $49 \%$ & Sangat kurang \\
\hline Keluwesan/ Fleksibelity & 2,5 & $80 \%$ & Baik \\
\hline Keaslian/Originality & 2,4 & $75 \%$ & Cukup \\
\hline Keterincian/Elaboration & 1,8 & $56 \%$ & Kurang \\
\hline
\end{tabular}

Dari data diperoleh bahwa hasil terbaik indikator kemampuan berfikir kreatif siswa adalah pada indikator keluwesan/Fleksibelity dengan skor rata-rata 2,5 atau 80\%. Dillihat dari kisi-kisi soal yang dikukur, siswa mampu memberikan macam-macam penafsiran pada suatu gambar, cerita atau masalah ada disekitar mereka.

Sedangkan hasil yang sangat kurang terdapat pada indikator kelancaran/ Fluency dengan skor rata-rata 1,6 atau 49\%. Jika dilihat dari kisi-kisi soal yang diukur, masih banyak siswa yang belum mampu membuat pertanyaan dengan jawaban yang relevan dengan informasi yang diberikan. Hal ini perlu diselidiki apakah penyebab rendanya indikator tersebut, apakah karna soal yang sulit atau siswa belum terbiasa untuk menyusun suatu soal bedasarkan perintah yang diberikan. 
Sedang indikator dengan kategori kurang adalah indikator keterincian/ Elaboration, dengan skor rata-rata 1,8 atau 56\%. Dilihat dari kisi-kisi soal yang diukur, siswa belum mampu untuk memecahkan suatu permasalahan dengan langkah yang terperinci. Seandainya mereka mampu memecahkan masalah yang ada mereka tidakbisa memberikan alasan secara terperinci penyelesaian masalah tersebut.

Pada indikator keaslian/ Originality mendapatkan skor rata-rata 2,4 atau 80\% dengan kategori cukup, dilihat dari kisi-kisi soal yang diukur, siswa mampu menganilis sesuatu permasalah yang ada disekitar mereka karena ketertarikan mereka terhadap permasalahan tersebut.

Sangat kurangnya hasil tes berfikir kreatif siswa sesuai hasil penelitian bisa disebabkan karna siswa belum terbiasa mengerjakan soal yang berisi teks atau cerita, atau juga soal yang motifnya menganalisis suatu permasalahan di sekitar mereka. Mereka hanya mengerjakan soal yang berbentuk sederhana tanpa memerlukan suatu analisa untuk menjawab soal tersebut. Oleh karna itu dalam proses pembelajaran siswa perlu dilatih untuk mengerjakan soal yang berbentuk analisis atau soal HOT sehingga siswa akan terbiasa untuk mengerjakan soal yang berbentuk teks atau narasi yang perlu untuk menganalisa ketika menjawab soal tersebut.

\section{Simpulan}

Kemampuan literasi sains siswa SMP N 11 Pekalongan dari nilai maksimal 40 sebesar 11,6 (29\%) dan dilihat dari indikatornya siswa yang mampu memahami fenomena sebesar 38,15 (53\%), mengidentifikasi permasalahan ilmiah sebesar 2,1 (53\%), menjelaskan fenomena ilmiah sebesar 2,2 (57\%), menggunakan bukti ilmiah sebesar 3,1 (79\%) dan menerapkan konsep sains secara personal,sosial dan global sebesar 2,5 (64\%).

Sedang kemampuan berfikir kreatif siswa SMP N 11 Pekalongan adalah 16,6 (56\%) dari skor maksimum 32. Jika dilihat dari kemampuan siswa berdasarkan indikator kelancaran/ Fluency sebesar 1,6 (49\%), Keluwesan/ Flesibility sebesar 2,5 (80\%), keaslian/Originality sebesar 2,4 (75\%), Keterincian/Elaboration sebesar 1,8 (56\%)

\section{Daftar Rujukan}

Mijaya, N.P.A.P., A.A.I.A.R. Sudiatmika, and K. Selamet, Profil Literasi Sains SMP Melalui Model Pembelajaran Levels of Inquiry. Jurnal Pendidikan dan Pembelajaran Sains Indonesia (JPPSI), 2019. 2(2): p. 161-171.

Muliyani, R. and Y. Kurniawan. Profil Kemampuan Berpikir Kreatif dan Peningkatan Hasil Belajar Kognitif Siswa SMP melalui Model Pembelajaran Kooperatif Tipe STAD. in PROSIDING: Seminar Nasional Fisika dan Pendidikan Fisika. 2014.

Nofiana, M., Profil kemampuan literasi sains siswa smp di kota purwokerto ditinjau dari aspek konten, proses, dan konteks sains. JSSH (Jurnal Sains Sosial dan Humaniora), 2017. 1(2): p. 77-84.

PISA,2010, Assesing fragmework key competencies in reading, mathemaics, and science, OECD Publishing

Pertiwi, U.D., R.D. Atanti, and R. Ismawati, Pentingnya Literasi Sains Pada Pembelajaran IPA SMP abad 21. Indonesian Journal of Natural Science Education (IJNSE), 2018. 1(1): p. 24-29. 
Puspita, L., N. Supriadi, and A.D. Pangestika, Pengaruh Model Pembelajaran Creative Problem Solving (CPS) Disertai Teknik Diagram Vee Terhadap Keterampilan Berpikir Kreatif Peserta Didik Materi Fungi Kelas X Man 2 Bandar Lampung. Biosfer: Jurnal Tadris Biologi, 2018. 9(1): p. 01-12.

Sunaryo, Y., Model pembelajaran berbasis masalah untuk meningkatkan kemampuan berpikir kritis dan kreatif matematik siswa sma di kota tasikmalaya. 2013, Universitas Terbuka. 